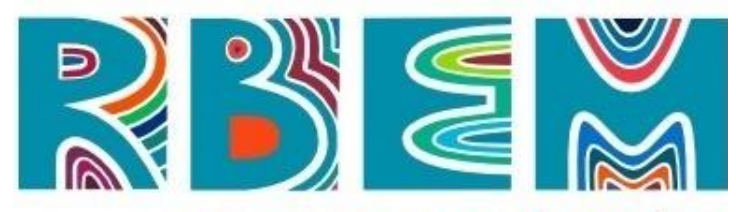

\title{
ARTIGO
}

do/ http://dx.doi.org/10.47207/rbem.v1i0.9237

\section{An Understanding of Socially-Constructed Knowledge in the Context of Traditional Game-Playing as Theorems-in-Action}

\author{
BRAZ DIAS, Ana Lúcia \\ Central Michigan University (CMU). Ph.D. in Mathematics Education from Indiana University. ORCID: \\ https://orcid.org/0000-0003-0674-0758. E-mail: dias1al@cmich.edu
}

\section{BRAZ DIAS, Juliana}

Universidade de Brasília (UnB). Associate researcher at Stellenbosch University (SUN) and University of Cape Town (UCT). Coordinator of the Laboratório de Etnologia em Contextos Africanos (ECOA/PPGAS/UnB). Ph.D. in Social Anthropology from Universidade de Brasília (UnB). Orcid: https://orcid.org/0000-0003-0316971X.E-mail: juliana.dias@unb.br

\begin{abstract}
In this article the authors describe data from an ethnographical study about the playing of Uril, a mancala-type game played in the island of São Vicente, Cape Verde. They interpret observed game strategies as theorems-in-actions, constructed socially and throughout a long period of time, influenced by socially shared norms and beliefs, as well as by knowledge construction at the individual level. The authors also use knowledge obtained from a computer-generated database to explore a sequence of game moves observed ethnographically, verifying its robustness and the necessary conditions that make it a winning strategy. The authors use evidence from ethnographical data to argue that those necessary conditions are tacitly assumed by the players observed.
\end{abstract}

Keywords: Ethnomathematics. Sowing games. Theorems-in-action. Capeverdean culture.

\section{Uma Compreensão do Conhecimento Socialmente Construído no Contexto de um Jogo Tradicional como Teoremas-em-Ação}

Resumo: Neste artigo, as autoras descrevem dados de um estudo etnográfico sobre o jogo de Uril, um jogo tipo mancala jogado na ilha de São Vicente, Cabo Verde. Interpretam as estratégias de jogo observadas como teoremas-em-ação, construídos socialmente e durante um longo período de tempo, influenciados por normas e crenças socialmente compartilhadas, bem como por construção de conhecimento a nível individual. As autoras também usam conhecimento obtido de uma base de dados gerada por computador para explorar uma sequência de movimentos do jogo observada etnograficamente, verificando sua robustez e as condições necessárias para que seja uma estratégia vencedora. As autoras utilizam evidências de dados etnográficos para argumentar que essas condições necessárias são assumidas tacitamente pelos jogadores observados.

Palavras-chave: Etnomatemática. Jogos de semeadura. Teoremas-em-ação. Cultura caboverdeana.

\section{Una Comprensión del Conocimiento Socialmente Construido en el Contexto de un Juego Tradicional como Teoremas-En-Acción}




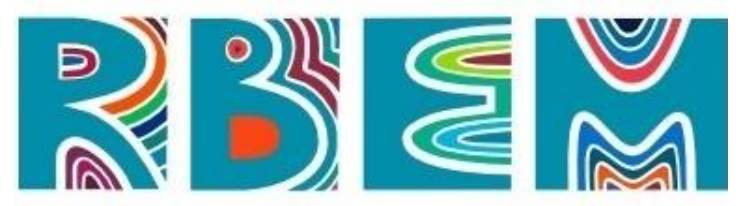

REVISTA BAIANA DE EDUCAÇĀO MATEMÁTICA

Resumen: En este artículo, las autoras describen datos de un estudio etnográfico sobre el juego de Uril, un juego tipo mancala jugado en la isla de São Vicente, Cabo Verde. Interpretan las estrategias de juego observadas como teoremas-en-acción, construidos socialmente y durante un largo período de tiempo, influenciados por normas y creencias socialmente compartidas, así como por la construcción del conocimiento a nivel individual. Las autoras también usan el conocimiento obtenido de una base de datos generada por computadora para explorar una secuencia de movimientos del juego observado etnográficamente, verificando su robustez y las condiciones necesarias que lo convierten en una estrategia ganadora. Las autoras utilizan evidencia de datos etnográficos para argumentar que esas condiciones necesarias son asumidas tácitamente por los jugadores observados.

Palavras-Clave: Etnomatemáticas. Juegos de siembra. Teoremas-en-acción. Cultura caboverdeana.

\section{Introduction}

This is a study about the construction of mathematical knowledge through the interplay between social and cognitive activities, in the context of a traditional game. The data analyzed in this paper were collected as part of an ethnographic study in which the authors, a mathematics educator and an anthropologist, sought to identify the meanings that Uril, a mancala-type game played in Cape Verde, acquires to its players, and how the playing of Uril relates to other spheres of Cape Verdean life. Data for this project has been collected in five different moments, in 2006, 2009, 2015, 2016, and 2017, using the ethnographic method (emphasizing participant observation), in the city of Mindelo, Island of São Vicente, Cape Verde. The project was partially funded (the 2006 fieldwork) by a Faculty Research and Creative Endeavors (FRCE) grant from Central Michigan University.

The broader goal of our research project was to relate the practice of Uril to the totality of Capeverdean life, especially to the socio-cultural reality of São Vicente, one of the ten islands that make up the archipelago. The reason for the choice to study Uril on the island of São Vicente was that this project is a continuation of research carried out in that location on the manifestations of popular Capeverdean culture by one of the authors (BRAZ DIAS, 2001). We consider the playing of Uril both in the context of Capeverdean culture and as a context from which we can learn the specificities of capeverdeaneity as a construct. This paper, however reports the results of two of our specific objectives, namely a) to investigate how Capeverdeans learn how to play the game and acquire expertise in it b) whether and how mathematical knowledge is constructed in the context of playing Uril. These two objectives are of greater significance to mathematics education. 


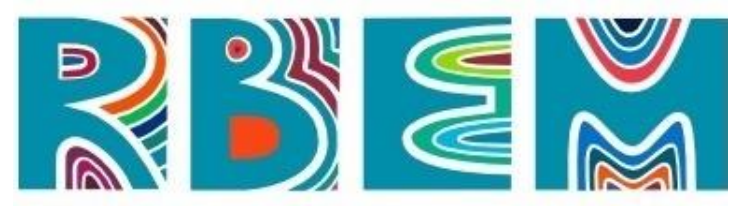

REVISTA BAIANA dE EDUCAC̣ĀO MATEMÁtICA

\section{Ethnomathematics}

Research on indigenous mathematical knowledge has become increasingly pursued since the 1980s and is frequently aggregated under the term ethnomathematics (D'AMBROSIO, 1985; ASCHER, 1988; KNIJNIK, 1993; GERDES, 1994b; KATZ, 1994; PINXTEN, 1994; ZASLAVSKY, 1994; GERDES, 1995; EGLASH, 1997b; 1997a; KNIJNIK, 2004; 2012) However, other terms have been used by authors with similar views: informal mathematics, street mathematics (CARRAHER et al., 1993), frozen mathematics (GERDES, 1994a), and sociomathematics (ZASLAVSKY, 1988). The fundamental idea behind these terms is that in the same way that different identifiable cultural groups produce their own value systems, symbolic systems, rites, myths and social practices, different cultural groups have their own techniques of counting, measuring, relating, ordering, classifying, evaluating and inferring — in other words, their own ways of mathematizing reality (D'AMBROSIO, 1991). Saying that there are different mathematics or ethnomathematics is a way of recognizing the various responses to the environment given by different cultural groups.

The application of the study of indigenous mathematics to the classroom has been widely discussed (MASINGILA et al., 1996; EGLASH et al., 2006; KNIJNIK, 1993). Research on ethnomathematics has also had the aim of understanding the construction and learning of mathematical knowledge (LAVE, 1977; MASINGILA, 1994). However, it has been argued that, on the one hand, ethnomathematical and sociocultural studies about the construction of mathematical knowledge lack an account of the individual as creator of knowledge, and, on the other hand, cognitive approaches have often not accounted for the social aspect of knowledge construction. Amidst this apparent fixture, games have been argued to be an ideal setting for investigating both cultural and cognitive processes (NASIR, 2005; MUNIZ, 2013). Game playing is a setting in which complex actions occur, both at the individual level, when the players seek to accomplish goals and solve situations in the course of the game, and at the social level, in which norms must be followed and interactions with others occur. Playing, as a form of sociability, combines the individual and social aspects of mathematical activity.

The ethnomathematics program proposes a dialogue with anthropological research. 


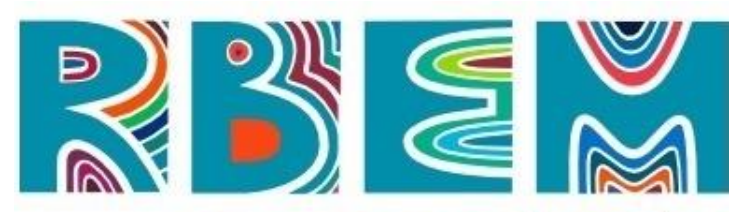

REVISTA BAIANA DE EDUCAC̣ĀO MATEMÁtICA

However, not all of its existing approaches are successful in the proposed interdisciplinary dialogue (CONNORS, 1990), thus the need for research done by interdisciplinary teams. Ethnographical methods have been advocated to study the culture of game playing and videogaming (ISMAEL, 2002; BOELLSTORFF, 2006), but we notice a relative absence of anthropological studies in which games are treated as inseparable phenomena from the sociocultural reality in which they are inserted (see, for example, SOARES, 1993; DE SOUZA, 1996).

This article aims at providing an account of knowledge creation and reproduction, through social and individual processes, in the context of the playing of Uril. In the process, we use academic language and categories, like mathematics, optimal moves, winning strategies, etc., which may or may not be shared by Uril practicioners (a possibility which is one of our research questions). Translating the practice of the game into academic language is not our ultimate goal, but a means to an end. In this sense, we understand the work of translation as a way to connect distinct cultural contexts. When describing mancalas (and Uril, in particular) through academic language, we assume the commensurability of different forms of knowledge and the possibility of discussing universal issues through particular case studies.

\section{Project design, methodology, and fieldwork}

This study was originally conceptualized as an ethnographical investigation back in 2006. However, the interpretive nature of ethnography and the open-endedness of the methodology of participant-observation and informal interviewing, made it impossible to secure funding and to obtain approval of institutional review boards for the project as research with human subjects at the time. Compromises were necessary on our part to finally obtain these two factors that were essential to start the project (funding and approval of ethics committees). The questions that originally inspired this study, which dealt with the relationship of mathematics to the whole of cultural life in a community, for which an ethnography would be the appropriate methodology, were narrowed to the identification of mathematical or proto-mathematical theorems (actually, conjectures or propositions taken-astrue) underlying the moves employed by subjects in specific game situations. 


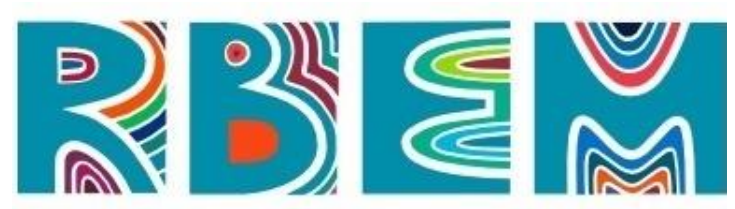

REVISTA BAIANA DE EDUCAC̣ĀO MATEMÁTICA

The first portion of fieldwork was conducted during Spring Break of 2006, with duration of 12 days. Despite the short duration, a lot was accomplished. Because the second author had done eight months of fieldwork in São Vicente and spoke Sanvincentean Creole, access to the groups of players and relationships were established. We walked throught the city of Mindelo and saw various sites in which Uril was played, but we focused our attention on Praça D’Uril, where many men played most afternoons, evenings, and nights (Figure 1). We did participant observations at that site daily and kept detailed fieldnotes.

We returned to fieldwork in 2009 (second author only), 2015, 2016, and 2017 (second author only) with a new review by Central Michigan University's Institutional Review Board (IRB), which under new direction has been tremendously more understanding and approving of ethnographical methods and the nature of our research objectives and research participants.

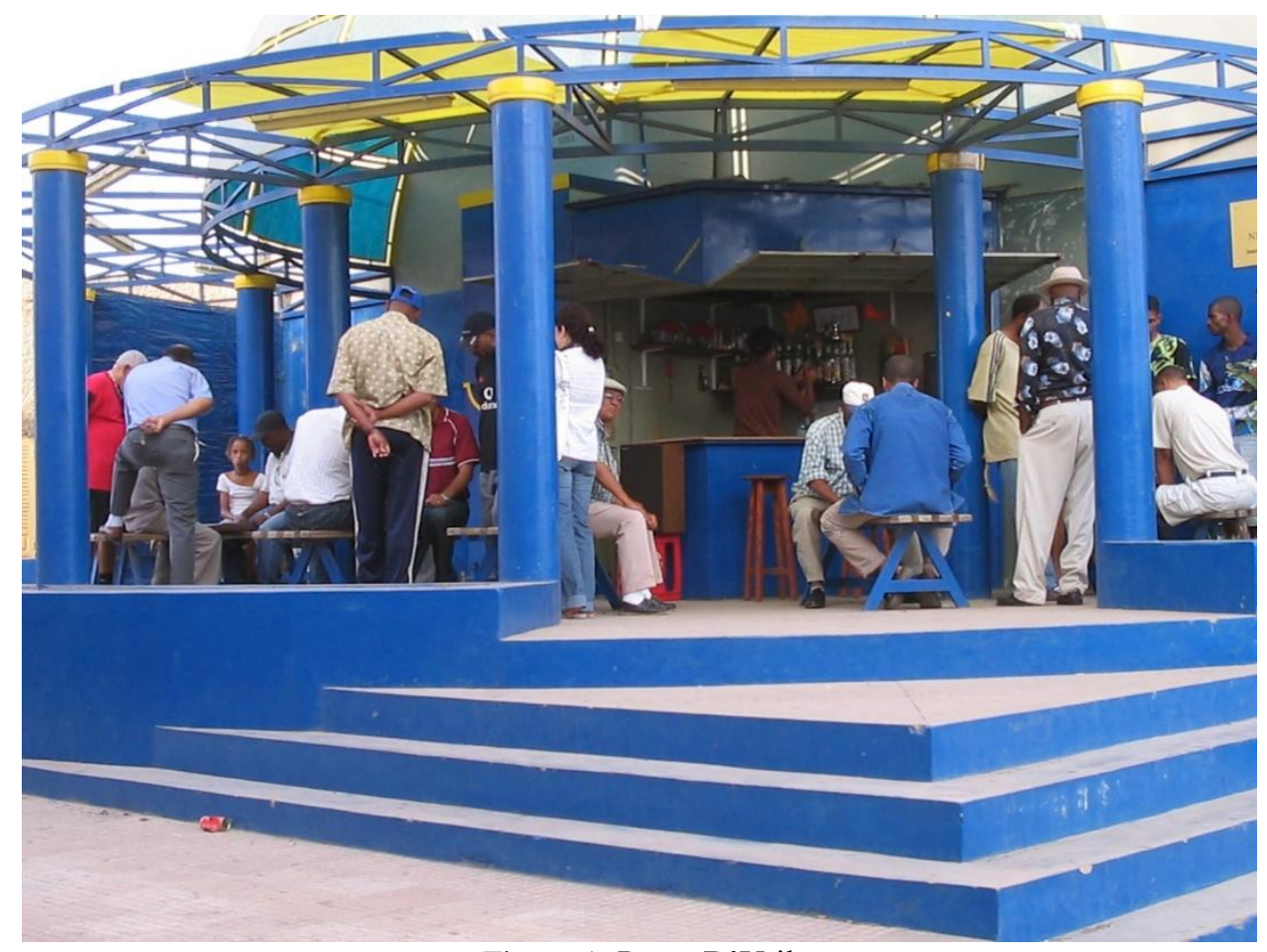

Figure 1: Praça D’Uril

The 2015 portion of our fieldwork was amazing in that we saw many of the same players we had met before, as well as new ones. And in that we learned that those who did not know us yet had heard about us. One player even said “oh, so they do exist!". Apparently the two Brazilian women who were so interested in their game and who played with them at Praça D’Uril had become somewhat of a legend. During that stay we continued with 


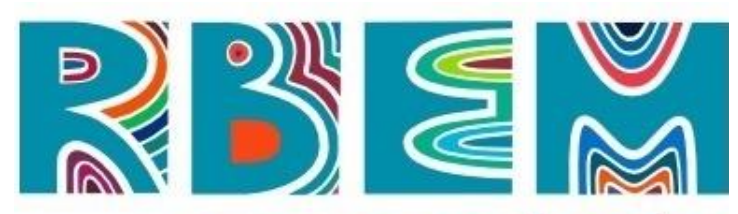

REVISTA BAIANA DE EDUCAC̣ĀO MATEMÁtICA

participant observation and did video recording of plays. We also conducted more formal interviews, which were recorded. That year, we recruited three social science students from Universidade de Cabo Verde to assist us with research at other sites. Upon returning home we worked at amending our project with IRB to include the three students, who obtained Collaborative Institutional Training Initiative certification, as research assistants. The assistants did observations at Ribeirinha (Ribeira Bote), Fonte Francês (Fund d`Saia), Praça de Ribeira de Craquinha, Chã de Alecrim (Rotunda), and Bar Bodizinho.

In 2016 and 2017 observations and interviews continued. In 2017 professional video footage was done and the life histories of three elderly expert players were recorded. The project is officially terminated on $7 / 5 / 2020$ and the authors plan to publish a book and a movie about it.

\section{Cape Verde}

Located approximately $500 \mathrm{~km}$ off the West coast of Africa, the Cape Verde archipelago (Figure 2) is home to a society which results from an elaborate process of social formation. From the encounter between Portuguese colonists and slaves from different parts

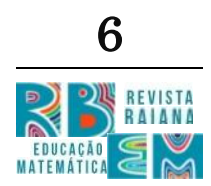
of the African continent, Capeverdean society was born and constituted as a synthesis of heterogeneous cultural elements. The marks of the close and prolonged contact between these diverse social groups are all over the archipelago and are strikingly revealed in the study of the Capeverdean culture and the values that guide the local population (BRAZ DIAS, 2000; 2004). The complexity of the creolization process that gave rise to Cape Verde can still be seen in its architectural features, in the ways of dressing and speaking, in the manifestations of popular culture, and in the acts of sociability of the population. It is also revealed in the game of Uril, whose origin brings to the fore the intricate relationship between the archipelago and the African continent, where similar board games are played in various regions (MIZONY, 1971; TOWNSHEND, 1979; DE VOOGT, 1999; 2005; ISMAEL, 2002). 

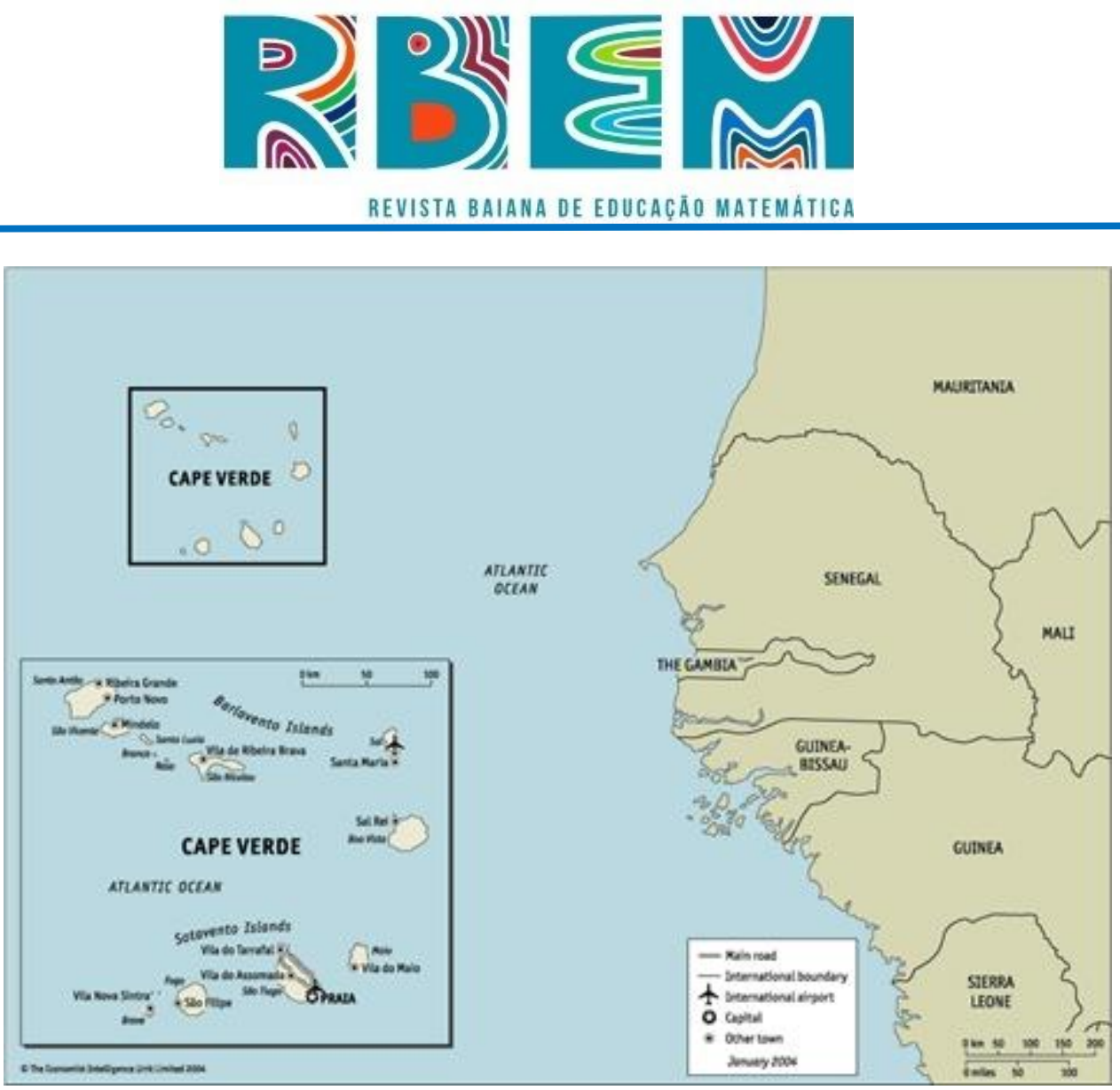

Figure 2: Cape Verde, West Africa.

\section{Capeverdean Uril}

The Uril game has a strong presence in the daily life of the islands. In rural and urban areas, we can often see men sitting on the sidewalks, on the doorsteps of the houses, or on park benches, playing Uril (Figure 3). The practice of the game is reproduced and renewed, reaching other parts of the world through the expressive number of Capeverdean nationals emigrated to other countries.

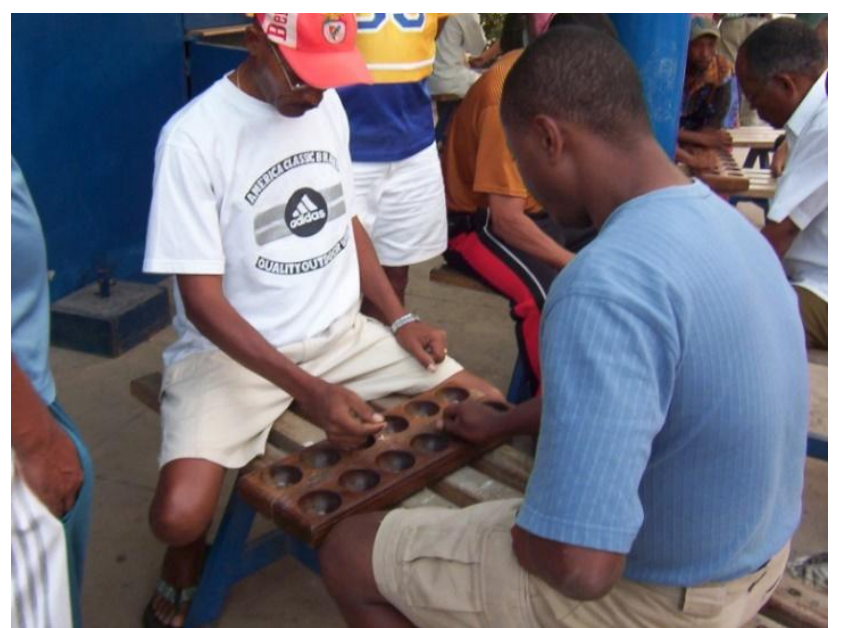

Figure 3: Men playing Uril in Mindelo, island of São Vicente, Cape Verde. 


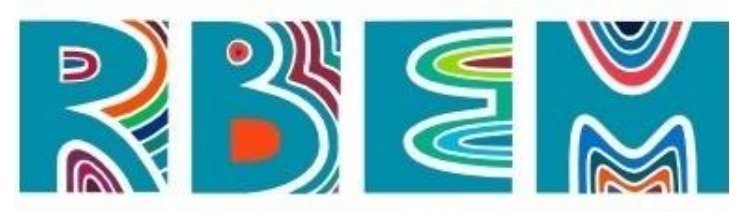

REVISTA BAIANA DE EDUCAC̣ĀO MATEMÁtICA

Although Luso-Capeverdean intellectuals have studied the archipelago's traditions for decades (see, for example, LOPES, 1956; FERREIRA, 1985; LOPES FILHO, 1995; ALMEIDA, 1998), Uril never received extensive attention in such studies. There are, however, quick references to the game, such as its description by Luís Romano in the glossary of his book (ROMANO, 1970). This is not to say that the game has not been addressed in other types of publications. For example, Silva (1994) described the game and its rules, addressing its practice in Portugal. In the field of education, Espinar Mesa et al. (2014) describe the rules of Capeverdean Uril and proposes a classroom activity about it for children in European schools. A local player from São Vicente, Albertino Graça, has published a book with rules and strategies of the game which was frequently referenced to us by other players (GRAÇA, 1998).

\section{Sowing games}

Uril is a traditional game which belongs to the class of games grouped under the generic name mancala. Variations of mancalas are played in almost all parts of sub-Saharan Africa, in the Caribbean, and in parts of the Middle East, and Central, South, and Southeast

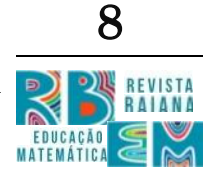
Asia (Townshend, 1979). Uril, Ouril or Ouri are local names for the versions played in Cape Verde.

The term mancala is used in reference to many distinct games, differing sometimes in rules, strategies, and even board configuration. The use of the generic term can then sometimes not be very informative. However, for the ethnic or social groups who play one or another version of the game there is no confusion, because each version has a local name by which it is referred, and the term mancala is not really used. The local names are then more informative because they allow us to determine what set of rules and practices to which one is referring.

Mancalas in general are games of no chance or of pure strategy, that is, games in which the results are not affected by chance. They are also games of perfect information, that is, games in which players know all the moves available to other players at all times during a match. Such games are also called combinatorial games (GUY, 1989). Within combinatorial games, mancala-type games are known as sowing games, a term inspired by the particular 


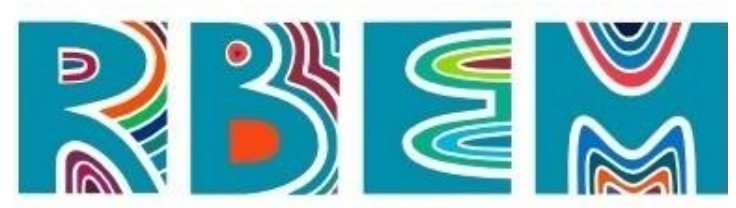

way in which the game pieces are moved on the board: "These games are played with a row of pots, each containing some number of seeds. The basic move consists of taking all the seeds from one pot and 'sowing' them one at a time into succeeding pots" (ERICKSON, 1996, p. 287). As we have said before, the number of pits on the board, the number of seeds, and the way captures are made are some of the variations possible within sowing games. There are also many other variations in rules - restrictions in moves, for example - that can make two or more versions of mancala quite different in the mathematical and strategic aspects.

This class of games has been said by researchers to involve more mathematics than chess does - despite the associations commonly evoked between mathematics and chess playing (DE VOOGT, 2005). The cognitive skills involved in playing versions of mancalas and possible uses for the mathematics classroom have also been investigated by various researchers (MIZONY, 1971; DELEDICQ; DESHAYES, 1976; RETSCHITZKI et al., 1986; POWELL; TEMPLE, 2001).

\section{The rules of Uril}

Uril is played by two players on a board with two rows of six pits and 48 seeds (Figure 4). At the beginning of the game, each player has four seeds in each pit. At their turn players choose one of the pits in their side of the board which to play. They then play by sowing the contents of the pit: getting all the seeds in the pit of choice and distributing its contents, one seed per pit, counterclockwise. 


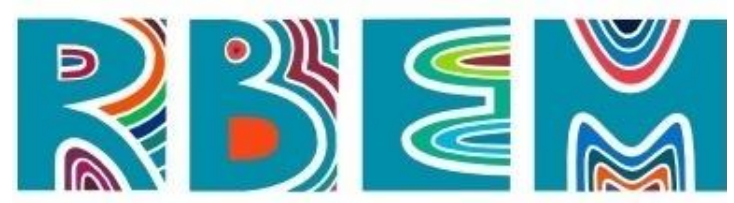

REVISTA BAIANA DE EDUCAÇÃO MATEMÁTICA

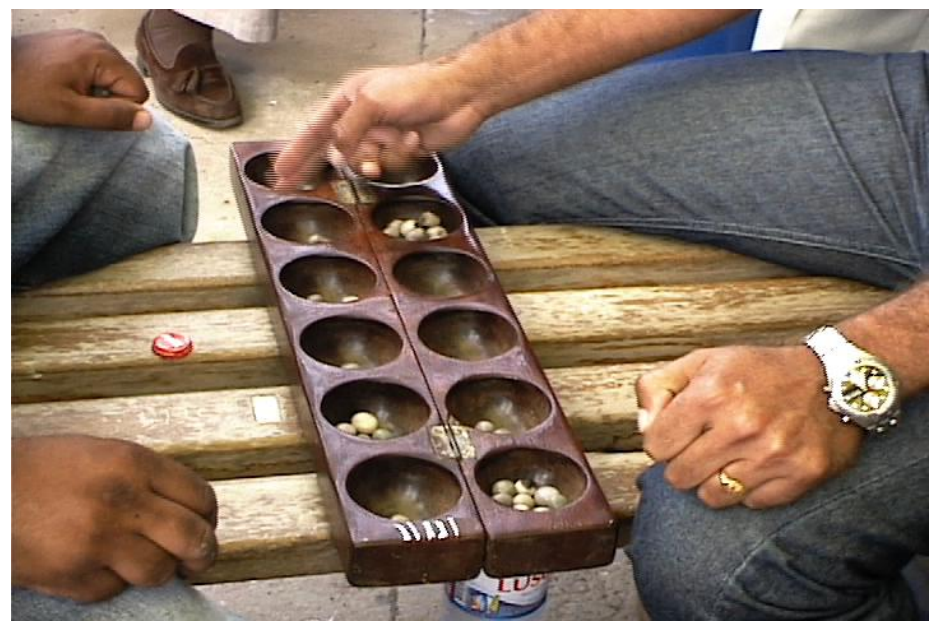

Figure 4: The Uril board.

The objective of the game is to be the first to capture 25 or more seeds. A capture happens when the last seed in a move is dropped into a pit on the opponent's side which had either one or two seeds. The resulting two or three seeds in that pit are then captured. If immediately previous pits also end up having two or three seeds, those are also captured.

For example, suppose the game is played by players South and North (South has the bottom array of pits, and North has the top array), and the configuration of the game at a certain moment is the one in Figure 5 below. Suppose also that it is South's turn to play.

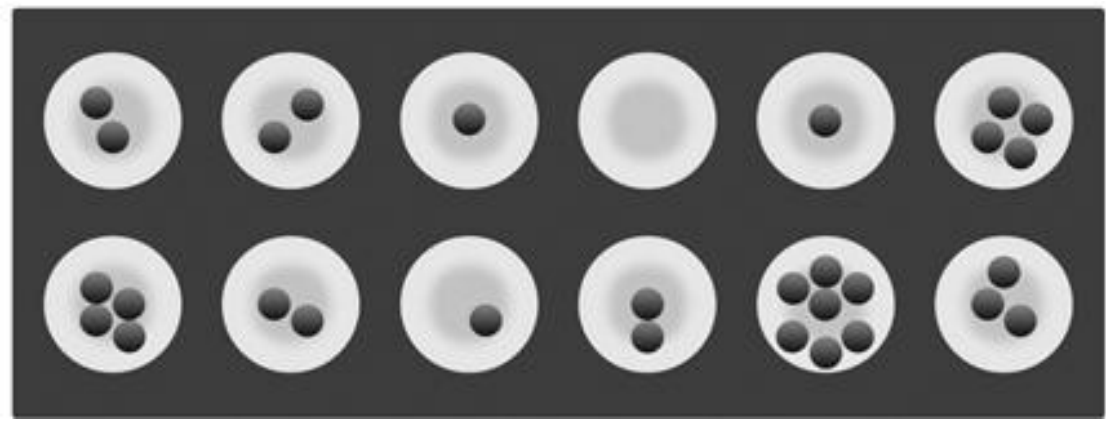

Figure 5: An example of Uril game configuration

Let us use the notation in Figure 6 to refer to the pits: 

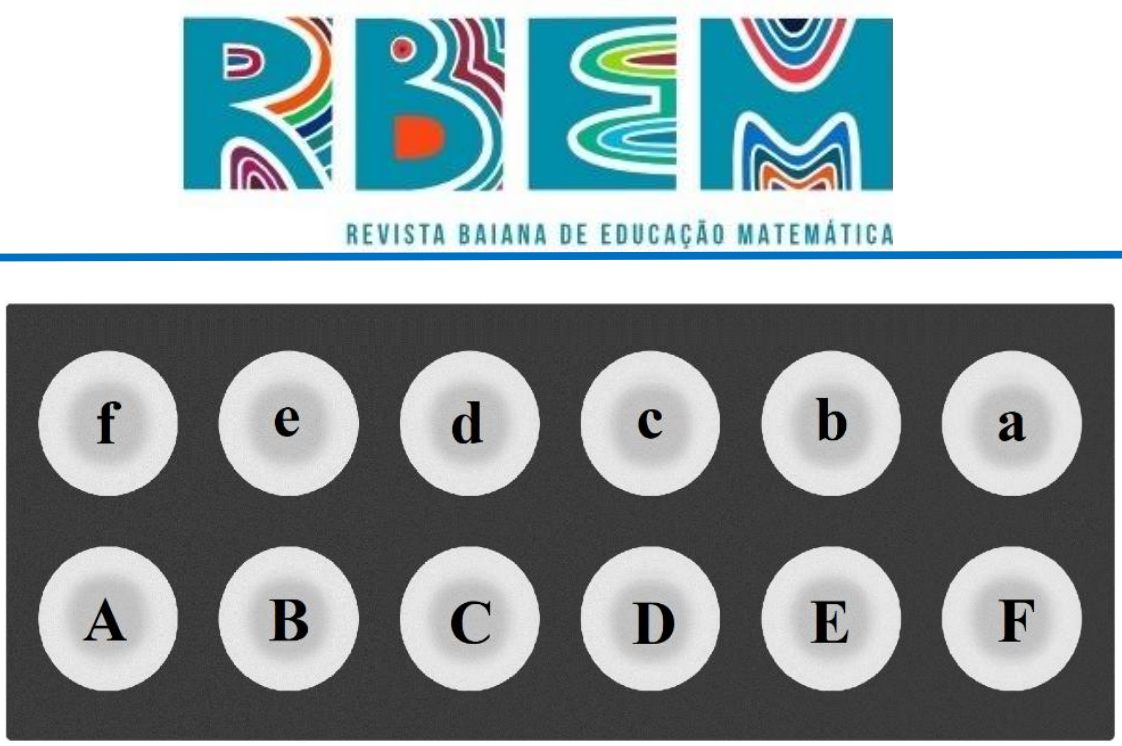

Figure 6: Labels for pits

If South chooses to play pit $E$, the last seed sowed falls in pit $f$. The resulting configuration, before capture, is shown in Figure 7.

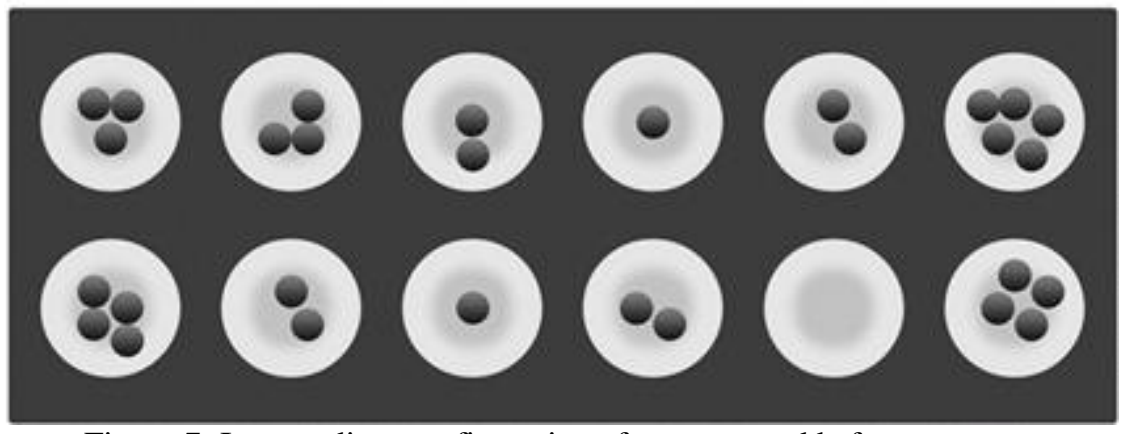

Figure 7: Intermediate configuration after move and before captures.

South then captures the contents of pits $f, e$, and $d$, because they contain three or two seeds each. Notice that pit $b$ also ends up with two seeds, but its contents are not captured because it is not adjacent to the other pits that participate in the capture (pit $c$ is between them and has only one seed). Figure 8 shows the result of the move after the seeds are captured. In this turn, South captured a total of eight seeds.

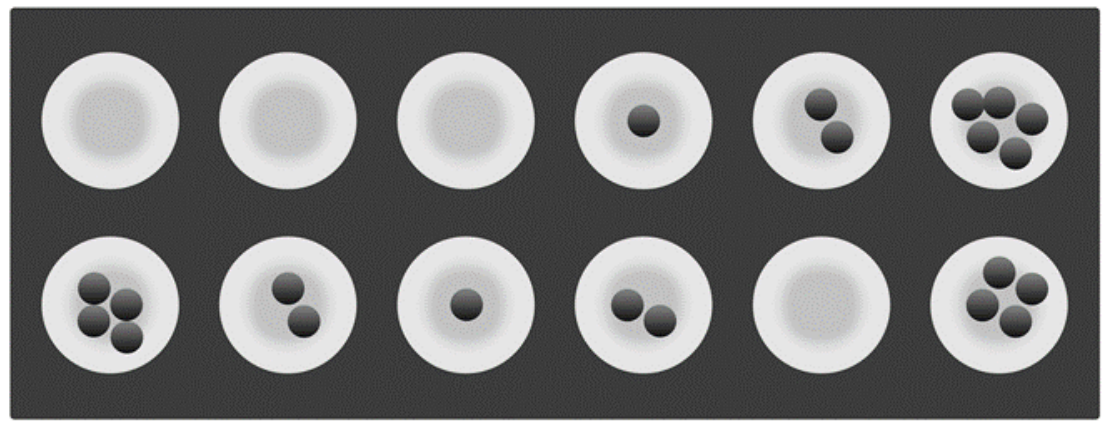

Figure 8: Configuration after seeds are captured. 


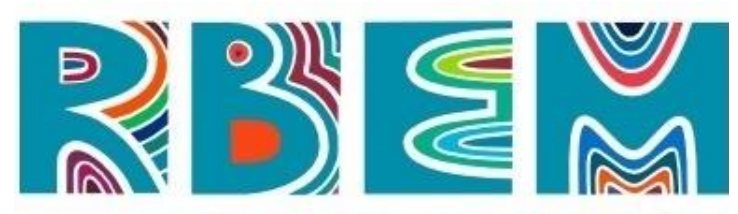

Finally, there are two other main rules in Uril:

(a) If one plays a pit that has enough seeds to go completely around the board (12 or more), the original pit is skipped and left empty.

(b) If a player does not have any seeds left, the opponent must make a move which will give him/her seeds. If it is the opponent's turn to play, but no such move can be made, the game is over and the opponent gets all the remaining seeds.

Other regulations concern more with the way in which the game is played, and are not going to be discussed in detail here. For example, in many variants of sowing games, the players are not allowed to hold and count the seeds in a pit. In Uril as played by those observed in this study, counting either one's own seeds or the opponents' is permitted at any time.

\section{Results and discussion}

We identified in the context of Uril playing categories that have been found useful in other investigations of Capeverdean culture: gender, seniority, and nationality play a part in this context as they do in other spheres of life. For example, at the setting where we conducted our fieldwork, the Praça d'Uril, only adult men played the game. A common theme we identified in players' assertions is that young people or children are not mature enough to play the game. This belief is contrasted with the fact that once in a while we would be told stories about a player or another who "was a very good player", and also very young; these cases, however, were always described as "exceptions" (and there were quite a few of them!) by the members of the group we observed. This shows that seniority is believed by those players to be a condition for expertise.

The separation of genders was evident. The players of Praça d'Uril told us that women also played the game, but elsewhere, usually at home. They often suggested to us that we practiced against one or another woman they knew that also liked to play the game. Nevertheless, they welcomed us (as exceptions) at the Praça D'Uril and seemed to enjoy sharing their knowledge with us (Figure 9). 

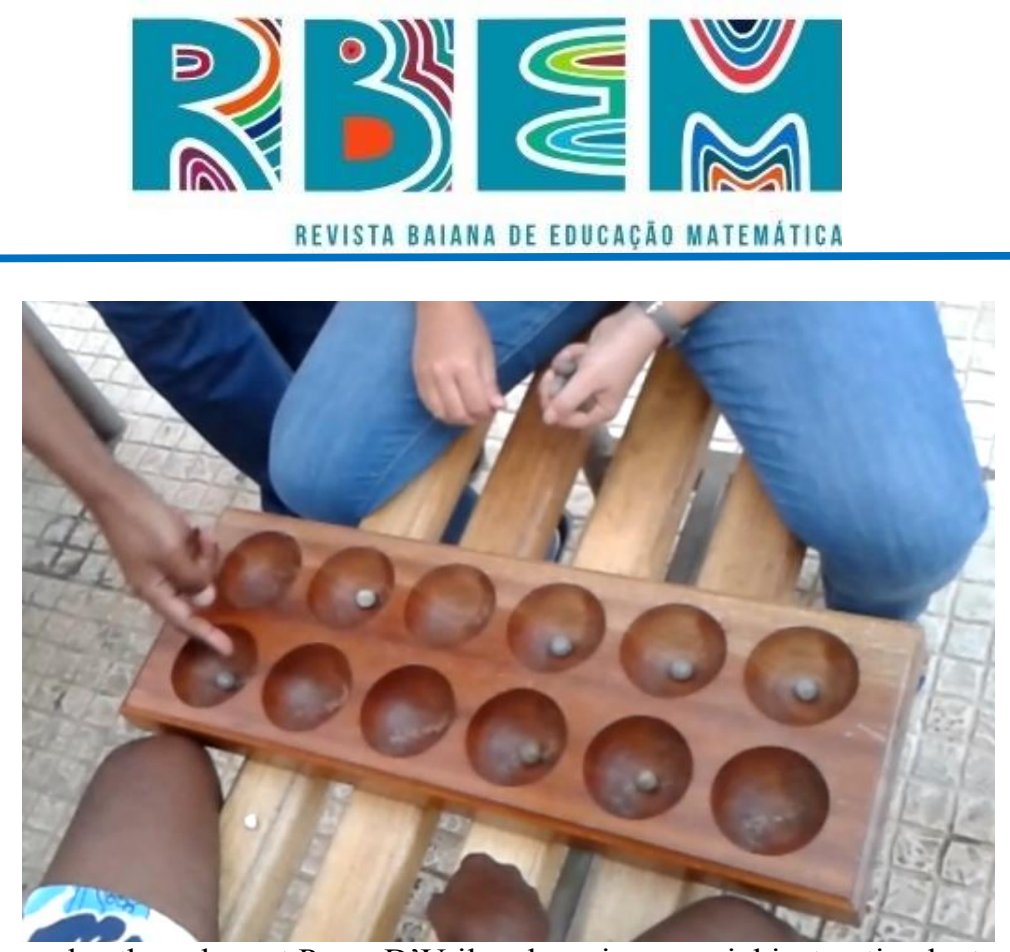

Figure 9: The second author plays at Praça D'Uril and receives special instruction by two of the research participants.

As for how one learns how to play the game, usually children start playing the so called jog'inglês, a version of the game which is considered to be easier. Later aspiring players can begin attending the places where seasoned players play, and by observation try to memorize plays and reenact them at home (according to data from one interview). We see that learning occurs largely by situated cognition and insertion in a community of practice (Lave, 1991). Although as researchers we received some direct instruction as a result of our

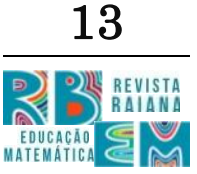
questioning, usually players learn by observing. Around each pair of players, a group of observers gather and follow matches at length. No questions are asked, but jokes are often made about a move being bad or other provocations occur which we see are opportunities for learning as well.

The name of that easier version is revealing, since it literally means English game. Our interpretation is that this indicates how mastery of Uril (in its original version) is linked, for those players, to socio-cultural origin. Capeverdeans (and African people in general) are expected to be better players than English (European) people.

We approached this project with the intention not to impose mathematics to the game as a category that might not make sense to the players themselves. However, during fieldwork it became immediately clear that the players consider the game to be mathematical. They frequently characterized the game and strategies to us as mathematics.

\section{An account of strategies as theorems-in-action}




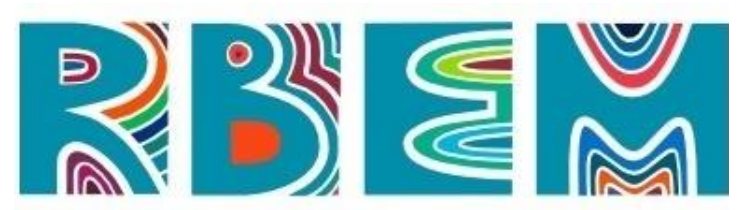

REVISTA BAIANA DE EDUCAÇĀO MATEMÁTICA

During fieldwork we came to learn a strategy for a specific endgame, which we will call 3-4. The endgame in question happens when one player has three seeds left in his/her side, and the other has four seeds left, positioned as in Figure 10.

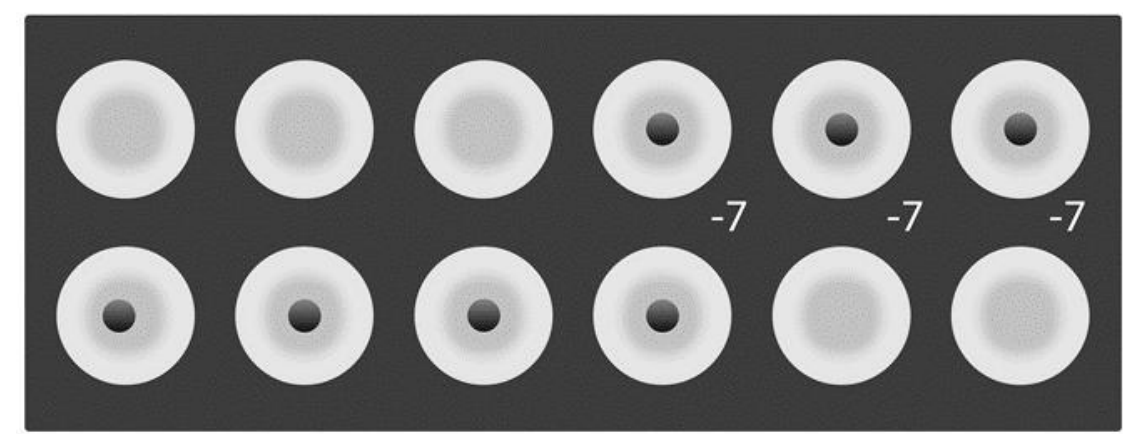

Figure 10: If player North is given this position to play next, South will capture all seven seeds on the board.

In our observations of expert players at Praça d'Uril (Uril Square), in Mindelo, Cape Verde, we saw that when this situation happens, players stop playing - the match is ended and the seven seeds on the board are counted as having been captured by the player with four seeds. The reason for this is that players hold the knowledge that, when that board configuration occurs and the player with three seeds is to play next, the result will always be the same: That player will lose all seven seeds.

We identify this as common knowledge, a formulation that today holds the status of obviousness. This strategy is social knowledge that is shared by a group of players, no one knowing exactly how it came to be known, but easily verified by practice: if one attempts to disprove it by actually continuing playing the game, it is assumed, one cannot be successful.

It is important to note that the expert Uril players we observed assume that players will play optimally, that is, will not make nonsensical or bad moves. When devising strategies, a player imagines a sequence of plays, many moves in advance, which only works under the assumption that the opponent will make the most rational move at each step. No chance is assumed. The way the other player is going to play is expected from the knowledge of the game and of the opponent. This was never verbalized or put forth by the players, but we posit the assumption was there by our observations. This was shown, we affirm, in the fact that most players carefully chose their opponents and at times refused to play against certain individuals they might consider weak players or novices.

The way that the 3-4 move is used or invoked as endgame evokes for us the 


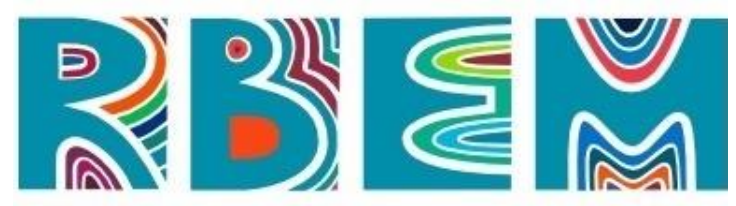

REVISTA BAIANA DE EDUCAÇĀO MATEMÁTICA

Vergnaudian concept of theorems-in-action. French mathematician and psychologist Gérard Vergnaud expanded the Piagetian theory of concept formation by affirming that action and activity is not only crucial for constructing operational knowledge, but that "action in situations and problem-solving is concept formation" (VERGNAUD, 1982, p. 34, our emphasis). Vergnaud has shown in his research that it is in action and in problem-solving that the learner identifies that there are some variables in a given context that remain invariant from one situation to another within that same context, and that this is precisely how people construct concepts. He calls those realizations "theorems-in-action": knowledge constructed by identifying these invariants. Vergnaud warns us that people do not encounter these theorems-in-action in a mathematical shape, nor would it make sense for teachers to explicitly teach them that way. In fact, some of these theorems-in-action do not occur to educators as a theorem; sometimes it is in conducting cognitive analysis of tasks and behaviors that we, researchers and educators, come to know them (Vergnaud, 1982).

It is a characteristic of theorems-in-action, according to Vergnaud (1982), that their formulation takes a long period of time, and it also takes the many interactions and gaps in knowledge that occur during problem solving. However, continues Vergnaud, at a certain stage of development they are taken as obvious properties of situations.

And while we posit that problem-solving and the construction of strategies and theorems-in-action have been happening in this setting at the social level, through interactions and social conventions, we have to point out that they also have been simultaneously happening at the individual level. We have been told by one player, for example, that he sometimes couldn't go to sleep, obsessing over a game position and trying to find a better strategy for it. This was a man who was considered by others as an exceptionally good player. Not being an apprentice, he already dominated the socially accepted knowledge, and sought to go beyond this knowledge by means of his own, individual solutions. He also demonstrated to be at the level of problem posing, or recognizing problems suggested by the game. This individual applied great effort in forming conjectures and testing them during play.

We have also observed an interesting instance, when one of the players wanted, at a certain point in the game, to stop the game, that is, declare game over, because for him the result was already known (he held a theorem-in-action about that game position). The other 


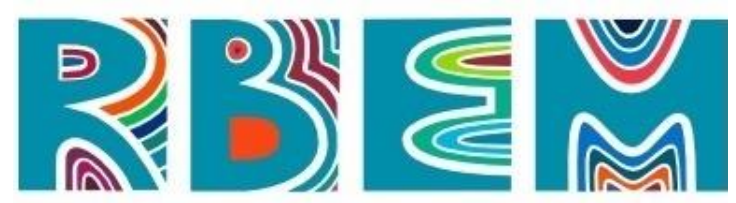

REVISTA BAIANA DE EDUCAÇĀO MATEMÁTICA

player, however, insisted that they kept playing, showing that this latter player had not constructed the same theorem-in-action, or even refuted it.

This interplay between social and individual constructions, all bounded by conventions and subject to refutations by the group mirrors the way mathematical knowledge is constructed in other settings (LAKATOS, 1976; COBB; YACKEL, 1996).

\section{Awari}

The rules of Uril are very similar to those of Awari, a mancala variant created by computer scientists in the 1990s. We used this fact to further study the game in between fieldworks, and we will use some of the knowledge about Awari to triangulate our data about Uril. Therefore, we now write a brief section on Awari.

Sowing games are particularly interesting to artificial intelligence because of the general properties of this family of games, which have been mentioned above: they are deterministic games (no chance involved), they have perfect information, and they are twoplayer games (DONKERS et al., 2001). Moreover, their rules are simple and yet the game has great complexity, since the number of possible positions is very large.

Awari is a version of sowing games with rules very similar to those of Uril in the way the game is set up and in the rules for capture. Awari is mainly played within the community of computer science and artificial intelligence, often in competitions where the players are different programs, not humans. Researchers aim at developing programs that will play optimally, and recently also at finding techniques that will allow a program to learn how to play better (DAVIS; KENDALL, 2002).

According to Donkers (2002), the rules for Awari were first published by Allis, van der Meulen, and van den Herik in 1990 (ALLIS et al., 1990). Although the rules are based on traditional forms of sowing games such as Wari, Awale, Oware, and Uril, as we have discussed before, there may always be at least slight variations from one version to the other, therefore the importance, among other reasons, to use the original nomenclatures of different versions of the game.

In 2002, Romein and Bal claimed to solve the game of Awari, by searching all possible positions of the game on a parallel computer with 144 processors (ROMEIN; BAL, 


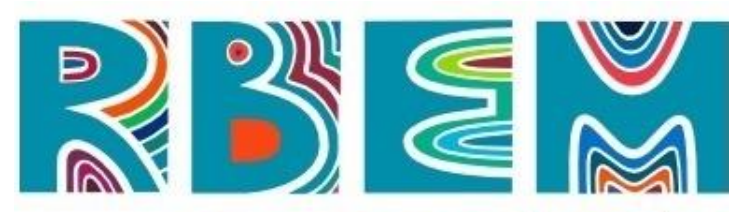

2003). They used the same rules as those published by Allis, Meulen, and Herik. For this set of rules, the number of possible positions is 889.063.398.406. The analysis they performed started in the final positions of the game and searched back all the way to all possible positions. The team of researchers made their The Awari Oracle available in a website which we used for subsequent sections in this article (ROMEIN; BAL, 2002b). The site has since then been moved or taken down, and we were no longer able to find it in 2020. The website provided a Java applet that allowed the user to play against the computer, which Romen and Bal claimed was a perfect player. Users could also use the edit mode to check the best score they could get if they play any given position (assuming that the opponent plays optimally). This is a major feat, since as they put it, "[n]o single computer has enough processing power and memory to search the state space, but even on a modern, parallel computer the problem was extremely challenging." (ROMEIN; BAL, 2002b, p. 162) We reproduced the data obtained for one given position in Figure 11. The numbers shown in the figure are the ending scores corresponding to each possible move, if the remaining of the game is played optimally, according to data produced by The Awari Oracle. The absence of positive numbers shows that if North is to play next, they will not be able to win.

Ten years after Romein and Bal's publication Awari is Solved (ROMEIN; BAL, 2002a) Blanvillain raised the question whether Oware is solvable at all (BLANVILLAIN, 2012). He cites results that indicate that the game cannot be solved by a computer without human intervention to manually enter solution for loops that occur in some cases. Nonetheless, Romein and Bal's database did a lot in improving our knowledge of the game. For one thing, they found out that there were some misconceptions about the game opening. Some openings that were believed to lead to draws have been shown to lose (ROMEIN; BAL, 2002a). For example, if South opens the game by playing pit $F$, it was believed (Romein and Bal do not specify by whom) that the only non-losing option that North had not to lose was playing $f$, but as Figure 11 shows, pits $e$ and $b$ also lead to a draw. 

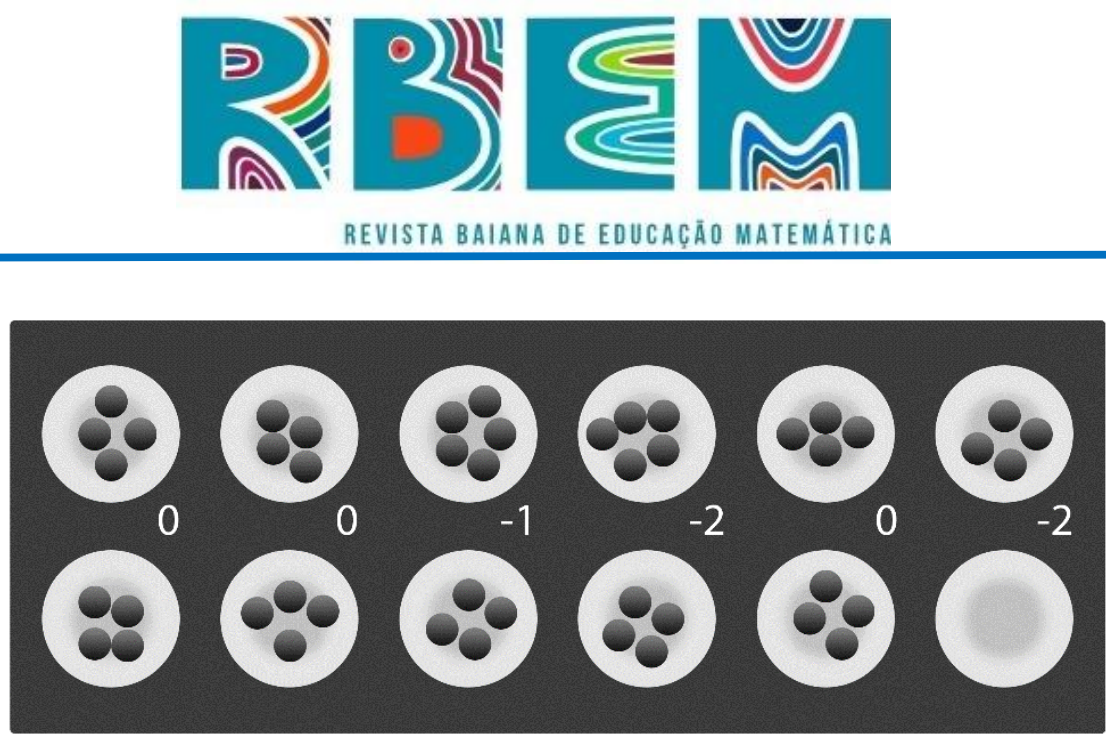

Figure 11: After South opens the game by playing pit $F$, North can lead to a draw if she plays $f, e$, or $b$. The negative numbers in the figure show that playing a, $\mathrm{c}$, or $\mathrm{d}$ will lead to losses.

Although it has been pointed out that Awari rules differ from those of games traditionally played by people in a couple of ways (DONKERS, 2002), we assume that these differences will not affect the result of our analysis. Namely, there is one rule in Awari that we did not observe in Uril: If a position is repeated three times, the game is ended and the remaining seeds are divided over the players.

Although Romein and Bal have not solved Awari mathematically, they did strongly solve it, that is, they determined a strategy for all legal positions of the game (VAN DEN HERIK et al., 2002). Similarly, we will not prove the theorem-in-action for the 3-4 position in a mathematical way, but will check whether, given the conditions in which the theorem is true, all strategies, for all the legal positions of the game will lead to confirmation of the theorem's thesis.

It is worth noting that the scores indicated for different moves in the Awari Oracle also use the assumption of optimal play. We were able to obtain scores different from the ones assigned by the program to certain positions by constantly making "bad moves".

By the way, the fact that not every human player plays optimally (or know what the optimal move would be) attests to the richness of the game. There is a level of mastery in which both players are reasonably good, but in which nonetheless the game does not become trivial, and problem-solving still goes on during play. It is also interesting to notice the effect of this condition on the result obtained by Romein and Bal (2002), that is, that the game is a draw if both players play optimally. They ask: "Did we ruin a perfectly fine game?" [by solving it] And immediately answer: "We do not think so." (p. 163) From our own perspective, the fact that even using the database there may be, for a given position, more than one good strategy now made known still leaves a wealth of challenges, even at expert level. 


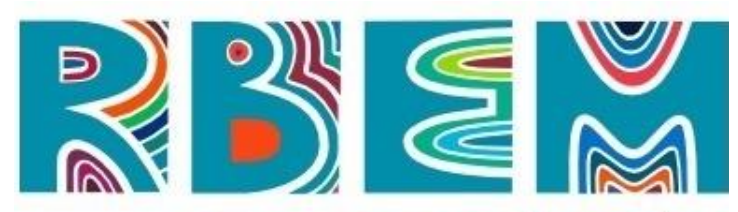

REVISTA BAIANA DE EDUCAC̣ĀO MATEMÁtICA

In other words, the game of Uril is deep in the sense proposed by Thompson (2015):

Depth means that human beings are capable of playing at many different levels of expertise. For most board positions, until the last stages of the endgame, the puzzle of finding the best move should not be completely solvable. In a deep game, a player must exercise nice judgment in deciding what is the best move in most situations. Depth gives a game lasting interest because the player continues to learn how to improve his play for a long time. (THOMPSON, 2015, p. 94)

\section{Investigating the theorem with the Awari Oracle}

Finally, how does the theorem-in-action we came to observe hold up against the information given by the Awari Oracle? Supposing both players play optimally; North and South have three and four seeds, respectively, and configured as shown in Figure 10; and North is next to move, the answer is yes, the theorem holds, according to the Oracle. Using the "edit" mode of the applet and inputting the configuration in which the "theorem" is applied, we obtain confirmation that North is going to lose the remaining seven seeds no matter which move he/she makes.

What if we relax the initial condition that both players play optimally? Can North still win? We played the game against the computer, who plays North, and we deliberately made bad move choices. What we found is that not only can North not lose its seeds, it can capture all seven remaining seeds. Figure 12 shows a game sequence, with corresponding scores for possible moves, that could succeed in the configuration shown in figure 10 if North plays pit $a$ and South does not play optimally. As the scores show, North could be in a position of capturing all seven seeds (indicated by $\mathrm{a}+7$ in the figure). Eventhough South is in advantage at the beginning, if they do not play the best move at all steps (see the transition from $c$ to $d$ in Figure 12, in which South chooses to play pit B - evaluated by the Awari Oracle to have a score of -7), North can gain the chance of recovery. 

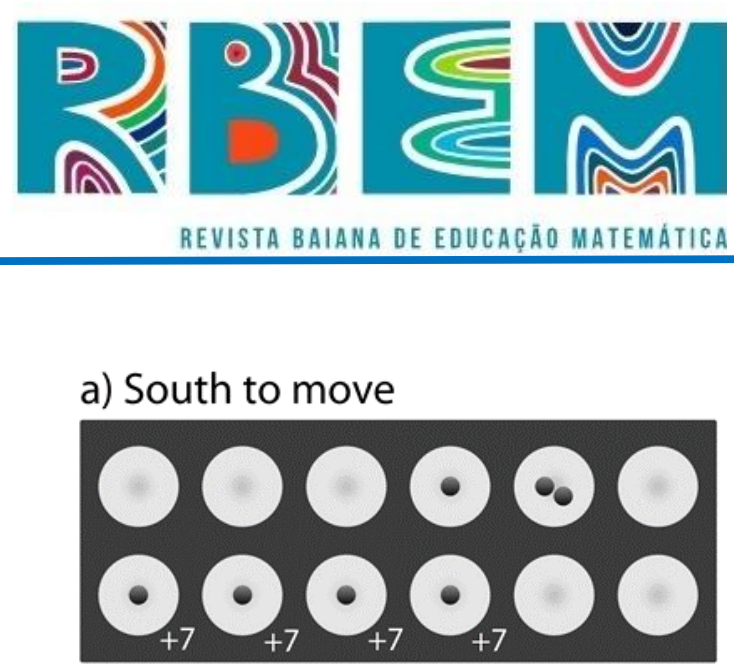

\section{b) North to move}

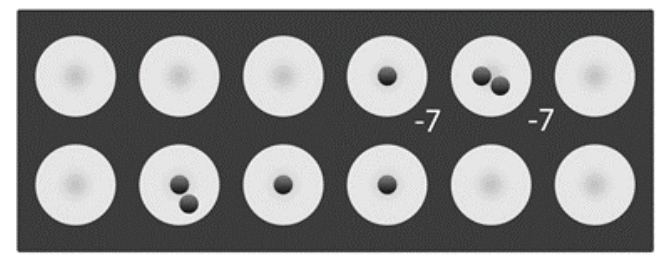

\section{c) South to move}

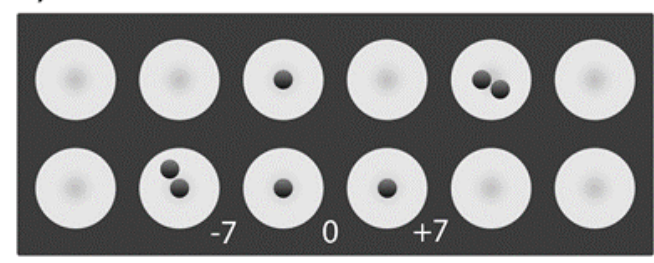

\section{d) North to move}

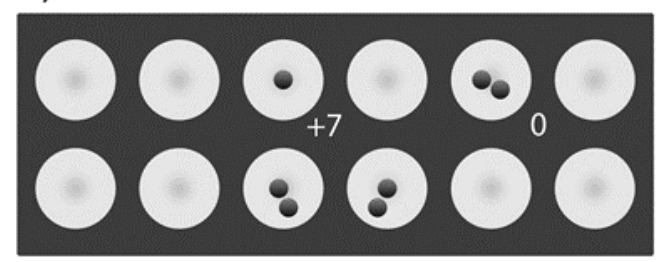

Figure 12: Although South is in advantage at the beginning, in step $c$ they choose to play pit B, which has a final score of -7 , and North recovers the possibility of capturing all seven seeds on the board.

This shows that the theorem-in-action that says: given the situation shown in Figure 10, and if North is to move, South will get all seven seeds has as necessary condition that both players make the best moves possible. If one of the players does not play optimally, the theorem does not hold. As we have said before, we posit that this condition is tacitly assumed by the players we observed, at all matches we observed in that setting, as are various other norms and beliefs, such as the conditions believed to be necessary for a player to excel in the game, such as seniority, nationality and possibly gender.

\section{Final Remarks}




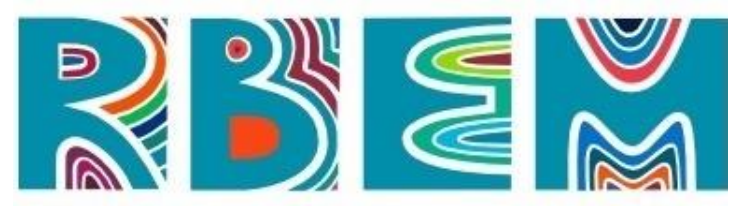

REVISTA BAIANA DE EDUCAC̣ĀO MATEMÁtICA

By investigating expert players of the game Uril in the city of Mindelo, Cape Verde, we have shown that knowledge is constructed, and problems are posed and solved during this traditional social practice that is game-playing. Being a practice that has been circulating for centuries, across time and spaces, the knowledge associated with this game is constructed and transmitted throughout a long period of time, but also constantly reconstructed socially and individually at particular times and spaces, such as the setting and matches we observed. We have shown how norms and beliefs - sometimes left unchallenged, possibly sometimes reelaborated - are an integral part of how problems are posed and solved within the group of players, and of how theorems are constructed in action - theorems sometimes accepted, other times refuted - during this traditional and long-lasting social practice that is the playing of Uril.

\section{References}

ALLIS, L. V.; VAN DER MEULEN, M.; VAN DEN HERIK, H. J. Databases in Awari. Technical Report CS-90-5. Maastricht, The Netherlands: Rijksuniversiteit Limburg, 1990.

ALMEIDA, J. M., Ed. Descoberta das Ilhas de Cabo Verde. Praia: Arquivo Histórico Nacional, 1998.

ASCHER, M. Graphs in Cultures - a Study in Ethnomathematics. Historia Mathematica, v. 15, n. 3, p. 201-227, 1988.

BLANVILLAIN, X. A. P. Oware: the oldest game of the world will not be solved by computers, 2012. Available at https://www.slideshare.net/XavierBlanvillain/abstract-owaresolutionxavierblanvillain120226. Retrieved in July 20, 2020.

BOELLSTORFF, T. A ludicrous discipline? Ethnography and game studies. Games and culture, v. 1, n. 1, p. 29-35, 2006.

BRAZ DIAS, J. Entre Partidas e Regressos: tecendo relações familiares em Cabo Verde. 2000. 211 f. Master's Dissertation (Master in Anthropology). Programa de Pós-Graduação em Antropologia Social, Universidade de Brasília, 2000.

BRAZ DIAS, J. Cultura Popular Cabo-verdiana em Ação. Unpublished manuscript, 2001.

BRAZ DIAS, J. Mornas e Coladeiras de Cabo Verde: versões musicais de uma nação. 2004. 265 f. Doctoral Thesis (Ph.D. in Social Anthropology). Programa de Pós-Graduação em Antropologia Social, Universidade de Brasília, 2004. 


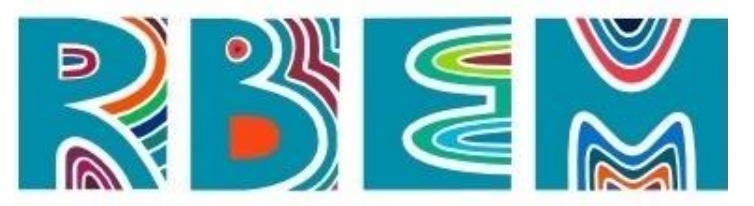

CARRAHER, T. N.; CARRAHER, D. W.; SCHLIEMANN, A. D. Na vida dez, na escola zero. São Paulo: Cortez Editora, 1993.

COBB, P.; YACKEL, E. Constructivist, emergent, and sociocultural perspectives in the context of developmental research. Educational Psychologist, v. 31, n. 3-4, p. 175-190, SumFal 1996.

CONNORS, J. When mathematics meets anthropology: The need for interdisciplinary dialogue. Educational studies in mathematics, v. 21, n. 5, p. 461-469, 1990.

D'AMBROSIO, U. Ethnomathematics and its place in the history and pedagogy of mathematics. For the learning of Mathematics, v. 5, n. 1, p. 44-48, 1985.

D'AMBROSIO, U. As matemáticas e o seu entorno socio-cultural. In: GARCÍA, M. (Ed.). I Congreso Iberoamericano de Educación Matemática. Sevilla, España, 1991. p.70-82.

DAVIS, J. E.; KENDALL, G. An investigation, using co-evolution, to evolve an Awari player. Proceedings of the Evolutionary Computation on 2002. CEC '02. Proceedings of the 2002 Congress. 2: p. 1408-1413, 2002.

DE SOUZA, M. A. A nação em chuteiras: raça e masculinidade no futebol brasileiro. 1996. Master's Dissertation (Master in Anthropology). Programa de Pós-Graduação em Antropologia Social, Universidade de Brasília, 1996.

DE VOOGT, A. J. D. Distribution of mancala board games: a methodological inquiry. Board Games Studies, v. 2, p. 104-114, 1999.

DE VOOGT, A. A question of excellence: a century of African masters. Trenton, NJ: Africa World Press, 2005.

DELEDICQ, A.; DESHAYES, P. Exploitation didactique du wari. Cahiers d'Études africaines, p. 467-488, 1976.

DONKERS, J. Comments on the Awari solution. Journal of the International Computer Games Association v. 25, n. 3, p. 166-167, 2002.

DONKERS, J.; UITERWIJK, J.; DE VOOGT, A. Mancala games: Topics in Mathemathics and Artificial Intelligence. In: (Ed.). Step by Step. Proceedings of the Colloquium Board Games in Academia IV. Fribourg, 2001. p.133-146.

EGLASH, R. Bamana sand divination - Recursion in ethnomathematics. American Anthropologist, v. 99, n. 1, p. 112-122, 1997a.

EGLASH, R. When math worlds collide: Intention and invention in ethnomathematics.

Science Technology \& Human Values, v. 22, n. 1, p. 79-97, $1997 \mathrm{~b}$. 


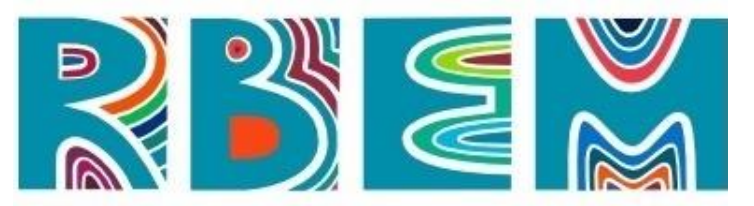

REVISTA BAIANA dE EDUCAC̣ĀO MATEMÁtICA

EGLASH, R. et al. Culturally situated design tools: Ethnocomputing from field site to classroom. American anthropologist, v. 108, n. 2, p. 347-362, 2006.

ERICKSON, J. Sowing games. In: NOWAKOWSKI, R. J. (Ed.). Games of no chance. Cambridge: Cambridge University Press, 1996. p.287-297.

ESPINAR MESA, G.; FERNÁNDEZ-OLIVERAS, A.; OLIVERAS CONTRERAS, M. L. El ouril como ejemplo del uso de los juegos culturales para la enseñanza globalizadora de las matemáticas, 2014.

FERREIRA, M. A aventura crioula. Lisboa: Plátano, 1985 [1ª edição: 1967].

GERDES, P. African Pythagoras : a study in culture and mathematics education. Maputo Moçambique: Ethnomathematics Research Project, Instituto Superior Pedagógico, 1994a.

GERDES, P. Reflections on Ethnomathematics. For the Learning of Mathematics, v. 14, n. 2, p. 19-22, 1994b. ISSN 02280671. Disponível em: < http://www.jstor.org/stable/40248110 >.

GERDES, P. Ethnomathematics and education in Africa. Stockholm: Stockholms Universitet, 1995.

GRAÇA, A. Jogo de oril: regras, estratégias e teorias. Mindelo: Edição da ONDS - Cabo Verde, 1998.

GUY, R. K. Fair Game: How to play impartial combinatorial games. Arlington, MA: COMAP, 1989.

ISMAEL, A. An ethnomathematical study of Tchadji: About a Mancala type boardgame played in Mozambique and possibilities for its use in mathematics education. 2002. $330 \mathrm{f}$. Ph.D. thesis, University of the Witwatersrand, Faculty of Science, Johannesburg, 2002.

KATZ, V. J. Ethnomathematics in the Classroom. For the Learning of Mathematics, v. 14, n. 2, p. 26-30, 1994.

KNIJNIK, G. An Ethnomathematical Approach in Mathematical Education: A Matter of Political Power. For the Learning of Mathematics, v. 13, n. 2, p. 23-25, 1993.

KNIJNIK, G. Etnomatemática e educação no movimento sem terra. In: KNIJNIK, G.;WANDERER, F., et al (Ed.). Etnomatemática, currículo e formação de professores. Santa Cruz do Sul, RS: EDUNISC, 2004. p.219-238.

KNIJNIK, G. Differentially positioned language games: ethnomathematics from a philosophical perspective. Educational Studies in Mathematics, v. 80, n. 1-2, p. 87-100, May 2012. 


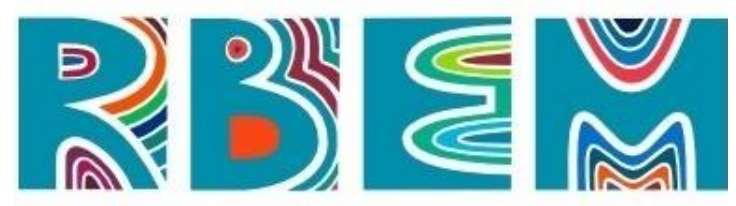

LAKATOS, I. Proofs and refutations: The logic of mathematical discovery. Cambridge: Cambridge university press, 1976.

LAVE, J. Cognitive consequences of traditional apprenticeship training in West Africa. Anthropology \& Education Quarterly, v. 8, n. 3, p. 177-180, 1977.

LAVE, J. Situating learning in communities of practice. Perspectives on socially shared cognition, v. 2, p. 63-82, 1991.

LOPES, B. Cabo Verde Visto por Gilberto Freyre: apontamentos lidos ao microfone de Rádio Barlavento. Praia: Imprensa Nacional, 1956.

LOPES FILHO, J. Cabo Verde: detalhes do quotidiano. Lisboa: Caminho, 1995.

MASINGILA, J. O. Mathematics Practice in Carpet Laying. Anthropology \& Education Quarterly, v. 25, n. 4, p. 430-462, 1994.

MASINGILA, J. O.; DAVIDENKO, S.; PRUS-WISNIOWSKA, E. Mathematics learning and practice in and out of school: A framework for connecting these experiences. Educational Studies in Mathematics, v. 31, n. 1, p. 175-200, 1996.

MIZONY, M. Les Jeux Stratégiques Camerounais et Leurs Aspects Mathématiques. Annuaire de la Faculté des Sciences de Cameroun, v. 6, p. 19-38, 1971.

MUNIZ, C. A. Brincar e jogar: enlaces teóricos e metodológicos no campo da educação matemática. Belo Horizonte: Autêntica, 2013.

NASIR, N. I. S. Individual cognitive structuring and the sociocultural context: Strategy shifts in the game of dominoes. The Journal of the Learning Sciences, v. 14, n. 1, p. 5-34, 2005.

PINXTEN, R. Ethnomathematics and Its Practice. For the Learning of Mathematics, v. 14, n. 2, p. 23-25, 1994.

POWELL, A.; TEMPLE, O. Seeding ethnomathematics with oware: Sankofa. Teaching children mathematics, v. 7, n. 6, p. 369-375, 2001.

RETSCHITZKI, J.; ASSANDÉ, N. G.; LOESCH-BERGER, M.-C. Etude Cognitive et Génétique des Styles des Joueurs d'Awélé. Archives des Psychologies, v. 211, n. 54, p. 307340, 1986.

ROMANO, L. Cabo Verde - Renascença de uma civilização no Atlântico médio. Lisboa: Edição da Revista “Ocidente”, 1970.

ROMEIN, J. W.; BAL, H. E. Awari is solved. Journal of the International Computer Games Association v. 25, n. 3, p. 162-165, 2002a. 


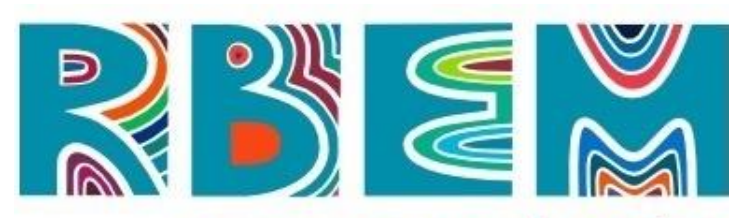

ROMEIN, J. W.; BAL, H. E. The Awari Oracle 2002b. http://awari.cs.vu.nl/awari. Accessed in 2006.

ROMEIN, J. W.; BAL, H. E. Solving the Game of Awari using Parallel Retrograde Analysis. Computer, v. 36, n. 10, p. 26-33, 2003.

SILVA, E. S. O “OURI”: Um jogo Caboverdiano e a sua prática em Portugal. Lisboa: Associação de Professores de Matemática, 1994.

SOARES, S. S. F. O jogo do bicho: a saga de um fato social brasileiro. Lisboa: Editora Bertrand, 1993.

THOMPSON, J. M. Defining the abstract. Game \& Puzzle Design, v. 1, n. 1, p. 83-86, 2015.

TOWNSHEND, P. African Mankala in Anthropological Perspective. Current Anthropology, v. 20, n. 4, p. 794-796, 1979.

VAN DEN HERIK, H. J.; UITERWIJK, J. W. H. M.; VAN RIJSWIJCK, J. Games solved: Now and in the future. Artificial Intelligence, v. 134, n. 1-2, p. 277-311, 2002.

VERGNAUD, G. Cognitive and developmental psychology and research in mathematics education: some theoretical and methodological issues. For the learning of mathematics, v. 3, n. 2, p. 31-41, 1982.

ZASLAVSKY, C. Integrating Mathematics with the Study of Cultural Traditions, 1988. Avaliable in https://eric.ed.gov/?id=ED303540.

ZASLAVSKY, C. "Africa Counts" and Ethnomathematics. For the Learning of Mathematics, v. 14, n. 2, p. 3-8, 1994.

Artigo submetido em: 26/07/2020

Artigo aceito em: 03/08/2020 